\title{
Elwira Buszewicz
}

http://orcid.org/0000-0002-6919-9105

Jagiellonian University in Kraków

elwira.buszewicz@uj.edu.pl

\section{The Ode as a Genre in the Latin Poetry of Jan Kochanowski (Lyricorum libellus) ${ }^{*}$}

\begin{abstract}
The aim of this study is to establish the place of Jan Kochanowski's Lyricorum libellus (1580) in the history of Polish Renaissance neo-Latin ode presented against a wider European background. The development of this genre in this historico-literary period in Poland has received only fragmentary reporting, e.g. in relation to Horatianism in literature or as a background for the vernacular ode. Yet, as Carol Maddison argues in her Apollo and the Nine, the Neo-Latin ode is, in a sense, a new genre revived and newly "devised" by Renaissance humanists. In her fundamental work, Maddison also presents the development of the ode and its variations in Italy and France. According to ancient patterns used by poets, Horatian odes (including Kochanowski's odes) can be divided into the "Pindaric" and the "AnacreonticSapphic." This division coincides to some extent with the classification of odes as "political" or "private." Similar categorisation criteria adopted by various researchers (Zofia Głombiowska, Jacqueline Glomski, Józef Budzyński) may result in individual odes being assigned to several different categories. The first part of this paper, therefore, emphasises the identity of the NeoLatin ode and its status as a new genre strongly related to Renaissance Humanism. In the second part, the author attempts to assign particular poems from Lyricorum libellus to patterns indicated by Maddison, and deals with previous attempts at classification based on differentiating between political and private odes. She also underlines that Kochanowski frequently

* The translation and publication was financed by the Ministry of Science and Higher Education (Poland) and the Faculty of Polish Studies, Jagiellonian University (Cracow, Poland) under Grant 643/P-DUN/2018 2. Polish text: E. Buszewicz, "Forma gatunkowa ody w łacińskiej poezji Jana Kochanowskiego (Lyricorum libellus)," Terminus 30 (2014), pp. 21-38.
\end{abstract}


imitated both pindaric and anacreontic patterns through Horace. In the third part, the author analyses the strophic organisation of individual odes and their metre as well as their rhetorical structure. The odes are here classified with regard to these criteria and interpreted in accordance with their historical context. The author pays close attention to the genre's borderline between ode and hymn, stylistic "nobilitation" of lyrical poems and the outright Horationism of the collection. Lastly, she presents conclusions concerning the role of Lyricorum libellus in the development of the ode. Before Kochanowski, a significant role in the evolution of the genre was played by the so-called "university ode," which was popular in Silesian and German poetic circles, as well as in odes by Paweł z Krosna. Kochanowski's odes, however, bear little resemblance to this stage of the development of the genre in Poland. Imitating Horace in the spirit of such poets as Michael Marullus or Giovanni Pontano, Kochanowski demonstrates a mature awareness of the neo-Latin ode, formed at the meeting point of ode and hymn and constituting an element of a cycle organised in accordance with a certain idea.

Keywords: Neo-Latin poetry, works of Jan Kochanowski, Horatian imitation, poetic genres, ode and its variations

\section{The Neo-Latin Ode-the "invention" of Renaissance humanists}

The monographer on this genre in Poland, Teresa Kostkiewiczowa, treated the history of the neo-Latin ode as a "necessary context," a kind of subsoil preparing the development of the finest vernacular form, that is-in her opinion-the Enlightenment ode. This is due to the assumptions she adopts, according to which "the subject of interest and description is primarily the history of the genre in the form it took in Polish." ${ }^{1}$ Therefore, she does not discuss Latin forms in very much detail, believing that there are significant differences

1 T. Kostkiewiczowa, Oda w poezji polskiej. Dzieje gatunku, Wrocław 1996, p. 29. 
in the ways in which this genre is realised in the Latin and Polish currents of our poetry, which require "reference to different contexts and even the use of different research tools."2 Despite the long history and noticeable continuity of the tradition, this suggests a certain separateness of the neo-Latin ode as a genre, which would therefore demand a separate monograph for poets connected to Poland.

Carol Maddison's Apollo and the Nine is an ever-increasingly instructive work (although probably not always in line with contemporary paradigms of philological thinking, and especially with those typical of Central European researchers) devoted to the neo-Latin ode. The argument is based on the observation that this genre was "invented" anew by Renaissance humanists, and its name ( $\omega \delta \eta \dot{\eta})$, taken from Greece, suggested an elevation of the more popular Latin word of the same meaning: carmen ("song"). Renaissance humanists, however, called the ode a special song, which presented the current, contemporary reality according to the taste and rules of antiquity. Both the ideological contexts and metric paradigms were determined especially by the influence of three ancient poets, first Horace, then Pindar, and finally Anacreon. This genre was characterised by greater formal rigorism and greater officiality than the unconstrained popular song. To put it briefly:

The form was concentrated and packed with allusion to all branches of human experience. It was the poem that glorified man, his experience, and his works. It was learned, formal, and public, rather than private or personal. With its constant allusion in metre and turn of phrase to the glorious past which was now set up as the classic or norm, the ode became a completely new type of poem. ${ }^{4}$

Even before Pindar spread his patronage over the neo-Latin ode tradition, Pindaric elements penetrated into its ideological structure

2 Ibidem, p. 28.

3 C. Maddison, Apollo and the Nine. A History of the Ode, London 1960.

4 Ibidem, p. 2. 
through Horace. It was thanks to him that a certain type of speaking subject, the character of the poet-priest, was formed. Not without significance was also the writer's conviction that the object of reflection was of universal importance and a specific generality of the object of his reflection, and that he perceived even individual events as a part of a universal continuum.

A certain amount of formality, then, a presumed audience, a sense of responsibility on the part of the poet, and imagery that relates the immediate subject to a larger context and adds fitting dignity and weight to the poem are all characteristics that are intrinsic to the ode, and all characteristics that were acquired from Pindar. ${ }^{5}$

Anacreontic poetry could have enriched the inventive space of the modern ode, as it was erudite, imitative and ceremonial. It inscribed the range of individual feelings in the universal experience of mankind, sanctified by tradition. ${ }^{6}$ Above all, however, the canon of Latin lyric poetry was shaped by Horace, whose poetry combine the motifs taken from Pindar and Anacreon as well as from Alcaeus and Sappho.

In this way, as Maddison observes, "Pindar the poet-priest, Anacreon the bon-vivant and Horace the pagan moralist" became the structural and ideological patterns of the new genre, which began to develop in the Renaissance. ${ }^{7}$ Stella Revard adds one more observation, perhaps surprising at first glance: Pindar's poetry also contributed to raising the style of the so-called light ode-among epinicia and other poems of Pindar, there are fragments that provide evidence that he was also, like Anacreon, a glorifier of the charms of life. ${ }^{8}$

5 Ibidem, p. 4.

6 Ibidem, p. 20. "They are imitations, ceremonious and learned, and not the impulsive expression of individual emotion but the traditional expression of universal human experience."

7 Ibidem, p. 38.

8 S. Revard, “The Graces in Their Merriment. Pindar and the Light Ode”, in: S. Revard, Pindar and the Renaissance Hymn-Ode. 1450-1700, Tempe 2001, pp. 277- 


\section{Kochanowski's ode and the structural and ideological patterns of the genre}

Kochanowski's odes have not often been analysed according to such a paradigm of patterns because it is not often pointed out in Polish historical and theoretical literary research. An attempt to look at the Lyricorum libellus in such a context is brought about by Jacqueline Glomski's study (still little known in Poland). ${ }^{9}$ Glomski points out that the main structural model of Kochanowski's Latin lyrical works was Horace's Carmina, while in terms of content individual odes can be classified as "Pindaric" or "Anacreontic-Sapphic." ${ }^{10}$ Pindarism was attributed by Glomski to six works on political and patriotic themes, whose character seems quite official and whose poetic depiction is majestic and rich. These are (according to the classification proposed by her) the following odes: 1. (Ad Henricum Valesium), 3. (In conventu Stesicensi), 4. (In Concordiam), 5. (Ad Nicolaum Firleum), 6. (In conventu Varsaviensi), and 12. (De expugnatione Polottei). The "Anacreontic-Saphic" odes were presented as lyrical statements of a more personal character, despite which a restraint and generalising tendency consistent with the requirements of the genre can be clearly seen. Thus, In deos falsos (2) is to be a statement on "reconciling pagan humanism with the Christian tradition," Ad Andream Patricium - a warning to a friend starting his ecclesiastical career, In villam Pramnicanam (10)-a description of an idyllic otium on a rural estate, Ad Vener (9) - an erotic and philosophical discourse, In equum (11) - an expression of personal feelings which, however,

317. Apart from examples taken from the epinicia, Revard particularly emphasises the work addressed to Teoxenos, described in scholia as the beloved boy in whose arms Pindar died (p. 281).

9 J. Glomski, "Historiography as Art. Jan Kochanowski's Lyricorum libellus (1580)," in: Renaissance Culture in Context. Theory and Practice, ed. by J. R. Brink, W. F. Gentrup, Aldershot 1993, pp. 145-154.

10 Ibidem, p. 147. 
have been "rhetoricized by the list of diatribes against a horse," while Ad Lycen (7) is a replica of an erotic Horatian ode revealing a characteristic distance. ${ }^{11}$

This is, of course, one of the possible suggestions for reading. The Horatian paradigm is paramount here, and within it there is also a place for the influence of Pindar or Anacreon. And indeed the spiritual patronage of Pindar can be seen in the "political" odes, but is Glomski's division of odes into "political" and "non-political" ones (called "private" by Zofia Głombiowska) ${ }^{12}$ unquestionable? Ode $\mathrm{V}$, addressed to Mikołaj Firlej, raises the most doubts in this respect. Glomski considers it to be a "political" poem, and therefore ideologically rooted in the Pindaric tradition. Głombiowska treats it as a "private" work. And more rightly so. "Ode V-as she aptly observes-is a moment of respite, a moment of exclusion from difficult political matters."13 And also: "Public affairs do not dominate the work [...]. The whole work is $[\ldots]$ an incentive for rest, wine and songs." ${ }^{14}$ The ode's content is, therefore, largely Anacreontic, filtered very clearly by Horatian motifs and ideas: "Custos sepositi villica Massici / Fumoso propere deme picem cado, / Et rorantibus hauri / Divinum laticem scyphis" (v. 17-20). ${ }^{15}$ With regard to Horatian imaging, the ode features not only the uncorking of an amphora and profuse consumption of wine, but also an encouragement known from the ode To Delius to celebrate on the grass, among the fragrances and flowers of a rose, in the shade of a tree called platanus, which can probably be considered as a classic addition of loftiness to a native "sycamore,"

\footnotetext{
11 Ibidem, p. 148.

12 Z. Głombiowska, Łacińska i polska muza Jana Kochanowskiego, Warszawa 1988, p. 80.

13 Ibidem, p. 87.

14 Ibidem, p. 83.

15 "Rural guardian of the reserves of Massican wine, / Hasten up to take the plug off the mossy barrel / and pour the divine drink / into the dewy cups." All quotations from the odes of Jan Kochanowski according to the first edition, translated by Kaja Szymańska: I. Cochanovii, Lyricorum libellus, Cracoviae 1580.
} 
in the shade of which Kochanowski would order the table to be set in the Sarmatian version of the ode Ad Delium. A careful reading of the stanza about the shade of the plane tree allows us to believe that Kochanowski cherished the Horatian idea, later referred to by literary scholars as "semiotic landscape ${ }^{16}$," in which the images of nature correspond to human behaviours and emotions. In To Delius, Horace mentions a pine and a poplar that lovingly intertwine their branches in order to enlarge the shade-this makes one think not only of soothing respite, but also of physical closeness, and perhaps even the physical love of people. ${ }^{17}$ In Kochanowski's ode V, the platanus "ictus calidi sideris igneos / parvipendit, amicta / spisso tegmine frondium" (v. 10-12) providing the pleasant shade and "dense leaves, neglects the fiery heat of the sun," which perfectly harmonises with the proposal to give in to a carefree otium in an uncertain political situation, when in the near unexpected future (the so very suggestive cras) a combat readiness, illustrated by an image of a dense leaf, may prove necessary. This ode also shows Kochanowski's finesse in combining different traditions, the ability (probably inspired by Horace) to intertextually "travel" within the genological universe: the second stanza also incorporates the bucolic key-we are dealing here with elements of Virgil's second eclogue. ${ }^{18}$

On the basis of this example, it can be stated that Kochanowski's Lyricorum libellus odes are difficult to classify as strictly "Pindaric" or "Anacreontic." Kochanowski's odes are "Horatian" not only in terms

16 The basic context for this term is the Polish title of the work of U. Eco, La Struttura Assente, (English version: The Absent Structure): U. Eco, Pejzaż semiotyczny, tłum. A. Weinsberg, Warszawa 1972. See also: J. Danielewicz, "Pejzaż semiotyczny w Pieśniach Horacego," Eos 63 (1975), pp. 297-302. About the ambiguity of the aesthetic code and the difference between the "technical" and "poetic" sense, see also: P. Guiraud, Semiologia, tłum. S. Cichowicz, Warszawa 1974, pp. 52-53.

17 See L. P. Wilkinson, Horace and His Lyric Poetry, Cambridge 1951, p. 129.

18 This can be seen in the description of the heat of the south and the cicadas dinning among the bushes. See Verg, Ecl. II, 13: "sole sub ardenti resonant arbusta cicadis." 
of their form. Their Horatian character is a kind of prism or filter through which ideas cherished by the poet from Boeotia or Theos, as well as the whole polyphonic richness of lyrical attitudes and alternative literary genres are passed through. ${ }^{19}$

Similarly, according to the rules shaped by Horace, the patronage of Pindar is revealed. According to Maddison, its main sign is the manifestation of the subject of the statement as a priest-poet-prophet. We see this clearly in ode I, in which Kochanowski declares his readiness to sing the future triumphs of Henry III of France: "Tum me nec Orpheus, nec fidicen Linus/Vincat canendo"20 (v. 37-38). The attitude of the "tensioner of the hope" can be seen at the end of Ode III: "Minas furentis ne nimium, o viri, / Horrete, sed nec temnite, barbari" (v. 41-42), ${ }^{21}$ here you can also see echoes of the "Absiste, vulgus" attitude, a sort of selection of the auditorium, which is to consist of cives integri, that is good-looking, noble citizens. The creation of the lyrical "I" as the priest of Muses and Apollo at the beginning of Ode VI: "Musarum et Clarii cultor Apollinis" (v. 1). The bard summoning the Muse is also the subject of the utterance in Ode XII. It is also possible to indicate a specific invention space resulting from the spirit of epinikia. We can say that this is a political reality, behind which there is a certain socio-ethical and religious order. ${ }^{22}$

Pindar is the best inspirer of official, occasional poetry, for which, starting from the Renaissance, he also became a formal model ${ }^{23}$-we

19 This polyphonic lyricism of Horace is discussed by Gregson Davis in Polyhymnia. The Rhetoric of Horatian Lyric Discourse, Berkeley 1991, passim. On the Vergilian and bucolic motifs, and on the other hand-elegiac ones, see pp. 181188. The most important thesis of this work is the rejection of the stereotype of superficiality and simplicity of Horace's song. The author reveals their multi-layered nature built on rhetorical topoi, recurring motifs and genological conventions.

20 "Then neither Orpheus nor the Linus playing a lyre will beat me in singing."

21 "Men! Do not be much afraid of the threats of a raging barbarian, but do not underestimate them either."

22 See A. Szastyńska-Siemion, “Wstęp," in: Pindar, Wybór poezji, Wrocław 1981, pp. XXIII-XXVI (BN II 199).

23 Ibidem, p. LVI. 
still remember two works by Kochanowski, imitating Pindar in terms of their metrics, namely Epinicion for Stephen Báthory and Epithalamion for the wedding of Jan Zamoyski and Griselda Báthory. These works also made one think of the tradition of choral lyricism, which, as it seems, required a musical setting and a public show. In the case of Lyricorum libellus, however, it is particularly interesting how the spirit of Pindaric poetry infiltrated Horatian metrics. According to Stella Revard, Pindar's influence can be seen not only in the forms of occasional political poetry, but also, and perhaps above all, in the development of the hymnic tradition and the formation of the genre of the hymn-ode. The same Italian poets-says Revard-who took the cult of Muses and Apollo over from Pindar (Giovanni Pontano, Michele Marullo, Pietro Crinito) began to write hymns to pagan gods and personified and divinised allegories, and they also wrote humanistic hymns to God and Christian saints. ${ }^{24}$ This tradition, also partly mediated by Horace, does not seem to be of little importance in Kochanowski's Latin lyrical work, since among the twelve odes we can find as many as three such forms of hymns. The hymnic character of Ad Concordiam and Ad Venerem is indisputable, while the last two stanzas of the ode In deos falsos is a prayer-a miniature hymn of praise in honour of the Judeo-Christian One God. The stylistic form taken over from Horace and Vergil covers the biblical material, relating to Psalm 51 (50). ${ }^{25}$ Perhaps in Kochanowski's mind the concept of the psalm upheld in the paradigm of the passage from the Horatian song crystallises more clearly (under the influence of Buchanan?). This genre, however, under Kochanowski's pen has acquired a native shape, not a Latin one. The "hymnic" character in the typically Horatian style is also present in ode X, in which the structure of the hymn (first covering the entire stanza of the apostrophe, then the development of the laudation initiated in it, and finally the

24 S. Revard, Pindar and the Renaissance..., p. 121.

25 J. Budzyński, Horacjanizm w liryce polskiej i łacińskiej renesansu $i$ baroku, Wrocław 1985, p. 79, associates the apostrophes of this work with the hymn of Czego chcesz od nas, Panie [litterally: "What do you expect of us, Lord."] 
prayer/wishes) is attributed not to the deity or a general concept, but to the work of human hands-here, the villa erected by Samuel Maciejowski, which is the residence of Piotr Myszkowski.

Maddison speaks pictorially about Pindar's "palette of colours," which includes almost exclusively "gold, silver, bronze, white and purple." ${ }^{26}$ Kochanowski, about whom it is often said that his epithets are conventional and his sense of painterly quality is weak, apparently holds on to this palette in his "official" odes. A golden crown, a silver spur and a triumphant quadriga harnessed with white steeds (only blue waters break this scheme) appear in ode I; in ode VI, there is golden sun, golden chariot of fame, purple-although stigmatised as foreign splendour and contrasted with domestic wool; in ode XII - a lute of ivory and the heat of flames. White and gold are also manifestly present in the hymnic odes, the "official" one (Ad Concordiam), which invokes associations with Horace's Hymn to Fortuna (Carm. I 35), and the "private" one (Ad Venerem), which is a translation of Sappho's poem. Interestingly, gold and purple can also be found in the "private" odes (often with a negative emotional tone, as in the ode addressed to Andreas Patricius).

As we know, the style of a lyrical work depended on its theme. Accordingly, it could be high or middle, sometimes even approaching the lower style. Kochanowski raises the style of an ode depending on the dignity of the addressee. They are often personae gravis (a deity, a ruler, a gathering of nobility). However, even those texts in which the style should be lowered, and indeed this is the case, have counterpoints that balance this lowered register. In the ode On a horse it is, for example, a description of the nether world or the praise of a mysterious nymph (a Muse? a personification of Poetry?), and in the ode To Lyce it is a reference to Amor and Venus "abandoning" an aging woman. Therefore, Kochanowski, like Horace, elevates ordinary matters. In this spirit, Giulio Cesare Scaligero interpreted the lyricism of Horace, appreciating both the lofty works of Flaccus in

26 C. Maddison, Apollo and the Nine..., p. 19. 
high style (e.g. Carm. 1-3), which he praised more than Pindar due to the lively sentences, as well as charming songs written in a lower style (e.g. Vitas hinnuleo..., Maecenas atavis, Quem tu, Melpomene semel..., Donec gratus eram tibi...), and expressing his praise very eloquently: "I would have preferred to write odes similar to those rather than to the many Pythic and Nemean ones by Pindar, I would have preferred to write ones similar to those rather than to be the king of all of Spain."27 This could confirm Revard's suggestion of the universal effect of such "filtered" Pindarism on the shape of the Renaissance ode, including the "light" variant.

In spite of their different functions, origins and destiny, all the odes of Lyricorum libellus fit in with Horace's poetic cosmos both thematically and structurally. Through him, they are also permeated by inter-genre relations ${ }^{28}$ and traditions associated with the great names of antiquity.

27 J. C. Scaliger, Poetices libri septem, Lugdunum (Lyon) 1586 (Liber VI, qui et Hypercriticus. Iudicium de aetatibus poeseos Latinae), p. 880. "Quarum similes malim a me compositas, quam Pythionicarum multas Pindari et Nemeonicarum, quarum similes malim composuisse, quam esse totius Tarraconensis rex." This peculiar cult of Horace is also visible a bit earlier (p. 879): "Carminum igitur libri vel iucunda inventione, vel puritate sermonis, vel figurarum novitate maiores sunt omni non solum vituperatione, sed etiam laude; neque solo dicendi genere humili, quemadmodum scripsit Quintilianus, contenti, verum etiam sublimi maxime commendandi" ["Thanks to apt invention, the purity of the language and the freshness of the figures, the books of Songs are not only beyond any criticism, but also beyond any praise; according to Quintilian, they are not limited to the low style, but they also ingratiate themselves to the highest degree using the lofty style."] Konrad Celtis treats lyrical works in a similar way, though without adding any Pindaric eminence: "A lyrical poem (poema lyricum). In it, they sing the praises of girls' games and the feasts of young men. He took his name from the lyre as during the feast a guitar and a lyre are delivered. This genre was exploited by Valerius Martialis, Cassius Bassus and Horace, and nobody can be compared with the latter; he was not neglected by Prudentius in Hymns" (transl. by Kaja Szymańska after J. Mańkowski, in: Poetyka okresu renesansu, oprac. E. Sarnowska-Temeriusz, Wrocław 1982, p. 16.

28 The relationship of the ode to the bucolic and hymn has already been mentioned. It is also worth mentioning the influence of the elegy (paraklausithyron) and epigram in the ode To Like. 


\section{Structures and forms}

The smallest structure that determines the formal shape of Kochanowski's odes is the verse (or stanza). As has been stressed many times, in the versification of Lyricorum libellus we find only the forms present in the poetic output of Horace. In this cycle the Alcaic stanza occurs four times, the second Asclepiadean stanza-three times, the minor Sapphic stanza-twice, the major Asclepiadean, the first Asclepiadean and the Alcmanian stanza-once. ${ }^{29}$ Kochanowski does not experiment within the framework of Horatian forms, he transfers poetic and strophic patterns in their entirety without blending them.

${ }^{29}$ The influence of the metric of the classical poets on Kochanowski's Latin works was mainly discussed by nineteenth-century researchers, e.g. P. Parylak, "O elegiach i odach łacińskich Jana Kochanowskiego z uwzględnieniem poetów klasycznych," in: Sprawozdanie Gimnazjum w Stanisławowie, Lwów 1880, pp. 3-15. A relatively recent look at Kochanowski's Latin versification through rigorous "lenses or learning" is Mieczysław Brożek’s text, "Łacińska wersyfikacja Jana Kochanowskiego. Próba charakterystyki," in: Cracovia litterarum. Kultura umysłowa i literacka Krakowa i Małopolski w dobie Renesansu [...], red. T. Ulewicz, Wrocław 1991, pp. 335-348. Lyrical patterns (the Alcaic, minor Sapphic, first and second Asclepiadean, major Asclepiadean, Alcmanian stanzas) are discussed on pp. 343-344. This opinion can be applied to the majority of the varieties of Latin lyric poetry by Kochanowski: the works are technically correct, consistent with the Horatian pattern, but what draws attention in them is... too many elisions! Pages 344-347 contain the characteristics of Pindaric works (in which again a multitude of ellipses was noticed with some exaltation). For example, Brożek is very surprised why Kochanowski arranged Epithalamion using verses that imitate Pindar and not any metrical paradigm known from Latin poetry. This should come as no surprise if one takes into account the above mentioned (underlined in the Revard's work) Renaissance postulate of Pindarising official works, and thus also occasional ones, connected with the life of important public persons. Kochanowski introduced the epinicion and the epithalamium to this lyric poetry, while he omitted the epicedium which would appear together with Szymon Szymonowic (on the death of Jakub Górski) and Andrzej Schoen (on the death of Stanisław Sokołowski). See W. Ryczek, Rhetorica christiana. Teoria wymowy kościelnej Stanisława Sokołowskiego, Kraków 2011, pp. 282-369. 
The majority of Renaissance poets (including Scaliger) divided the carmina lyrica also into other structures, showing the variety of metric arrangements and the strophic organisation of the text. A poem in which only one metric sequence repeats regularly (e.g. the minor Asclepiadean, the major Asclepiadean) was called monocolos, a piece in which the poem is arranged in alternating distiches of different metric structure-dicolos distrophos (and if two metric sequences were arranged in a four-line stanza-dicolos tetrastrophos), if there were three types of verse, arranged in a four-line stanza-for example two minor Asclepiadean lines, a pherecratean verse, a glyconic verse-tricolos tetrastrophos, etc. According to such a classification, Kochanowski's odes would be described as follows: I, II, III, V, VIII, $\mathrm{X}$, XII-ode tricolos tetrastrophos; IV, VI, IX-dicolos tetrastrophos, VII-monocolos, XI-dicolos distrophos.

The logical structure of Kochanowski's odes, like Horace's songs, sometimes takes the three-part structure of the Pindaric ode, and sometimes the finesse of the epigram. Examples are best shown in short forms, which is obvious in the second case. The Ad Lycen ode is, of course, an example of epigrammatic finesse, stylistically maintained in the lower sphere of the middle level, with an emphasis on the forceful punchline: "Scilicet ut satur ructet carnem alius, reliquis pascar ego ossium." 30 The three-part structure can be observed in the ode In deos falsos. The equivalent of a "strophe" would be the first three Asclepiadean-glyconic stanzas devoted to the pagan religion of the past, the equivalent of "antistrophe" could be found in a fragment (one stanza) corresponding, by way of antithesis, to the Christian present that buried all these deities in the darkness of Orcus, while a kind of "epode" is to be found in a two-stanza hymn to the Only God, which at the same time explains the idea of true piety.

The rhetorical structure of the genre used by Kochanowski is visible at different levels. We can point out here the efficient use of

30 "Probably in order for me to gnaw the remains of bones when another one has already eaten more than enough meat." 
antithesis, anaphora, alliteration, hyperbaton, elaborate apostrophe, metaphor, irony-both figures of words and thoughts, as well as tropes. The Lyricorum libellus should be considered against the background of Renaissance treatises on poetry. Scaliger devoted a lot of attention to poetic figures, and the value of poetry (not only lyrical, but poetry in general) was determined, according to him, by four virtutes: prudentia, varietas, efficacia, suavitas. ${ }^{31}$

According to Scaliger, figures of thoughts and rhetorical genres are also associated with the functions of whole works. Thinking about the phenomena that can be captured in lyrical measures, Scaliger shows that the treasury of invention implicitly contains figures of persuasion, praise and reprimand. In the centre of the lyrical plot stands the poet, his decisions, views, willingness to preach moral doctrine or to present a more general situation:

Whatever is appropriate for a short poem, it is right that it should be provided in lyrical measures. Praise, feelings of love, controversy, scorn, commessatoria, reprimands, wishes, encouragement to be free [or] on the contrary-recommendations of sobriety, general explanations of deeds, desires, regrets, explanations of places and times, new resolutions, thinking, undertaking matters, rejection of those already undertaken, invitations, rejections, determents, curses, if there are any other. But this kind likes spiritual freedom [...]. It requires, however, a large number of sentences [...]. Horace liked conciseness and we also recommend it as much as possible. For nothing is more pleasant than tasting many dishes. ${ }^{32}$

Scaliger points here to certain rhetorical functions: laus, vituperatio, recusatio, accusatio, etc. Such a distinction was probably fun-

31 J. Mańkowski (Poetyka okresu..., p. 265) translates them into Polish as: roztropność, różnorodność, skuteczność, słodycz (prudence, diversity, effectiveness, sweetness-K. S.). It is worth mentioning that in Scaliger's argumentation prudentia is actually erudition and substantive correctness, while efficatia is the power and energy of words manifested, among other things, in imaging skills.

32 Translated by K. Szymańska after the Polish translation by J. Mańkowski. See ibidem, pp. 295-296. 
damental for the division of odes according to the dicendi genera, ${ }^{33}$ which developed later, which we still use eagerly today and which was formulated, among others, by Maciej Kazimierz Sarbiewski. However, we generally do not treat the vituperatio or dirae forms as a separate "accusatory" type, ${ }^{34}$ related to the genus iudiciale, but as a possibility set out by the genus demonstrativum (reprimand as a mirror image of praise). Encomiastic odes that represent the genus demonstrativum are therefore odes IV, IX, X, XII, while odes II, VII and XI are criticising, imprecating or mocking. The genus deliberativum includes odes III, V, VI, and VIII. Sometimes these rhetorical functions can be defined more precisely, for example in Ode I it is invitatio, in VII recusatio, in XI maledictio, etc. They often contain counterpoints, mostly antithetical. In Ode I invitatio is permeated with laudation, in Ode II the "unmasking" of false gods is contrasted with the burial of the Lord, and in XI the scornful execration of the horse gives way to the praise of a mysterious nymph.

The basic postulates of the lyrical form enlisted by Scaliger are brevitas and varietas, quite important in the cyclic composition. The Lyricorum libellus is certainly the first collection of Horatian odes in the history of Polish poetry, consciously arranged according to these principles. Brevitas can be determined with mathematical precision;

${ }_{33}$ M. K. Sarbiewski, "Characteres lyrici seu Horatius et Pindarus - Charaktery liryczne, czyli Horacy i Pindar," in: Praecepta poetica - Wykłady poetyki, transl. by S. Skimina, Wrocław 1958, p. 22 (English translation-K. S.): "One genus is epideictic, and its content gives rise to the name of encomiastic, or laudatory odes [...]. Another one is deliberative, which gave its name to ethical odes, full of sentences and moral teachings, which either advise or discourage from doing something. The third type is similar to the judicial one, which contains execrations. This one includes curses, such as those hurled in Book II 13 at a tree that in falling almost killed the poet on the estate in Sabina, and in Epoch 3, where the poet cursed garlic."

34 However, in a sense, despite all the finesse of the structure of Ode XI, it contains elements of this genus dicendi. A reference to the accusatory speech could, for example, be suggested by the final suggestion that an unfortunate steed be sentenced to be deported to a mine... 
the length of individual odes is generally between 20 and 48 verses. The only exception is the last ode on the conquest of Polotsk, which is 100 verses long, but even this one is not excessively long, which is a frequent defect of neo-Latin imitations of Horace. ${ }^{35}$ Varietas, clear and consciously used, concerns both the subject matter and the metric. Odes written in the same metre are never next to each other. Józef Budzyński discussed in detail the composition of the collection in terms of the subject matter, its affinity with Book IV of Horace and the principle of variatio in harmonious lines of thought. ${ }^{36}$ In any case, there is a great variety here, which is not so easy to achieve in a collection of only twelve songs. Kochanowski alternates laudatory and criticising odes, "political" and personal ones, or persuasive and prayer-hymnic ones. Let us try to fully fathom this varietas. Ode I is deliberative, political, Ode II is epideictic, hymnic, with a social context, Ode III is political, deliberative; Ode IV is hymnic, epideictic, with a political context, Ode V is deliberative, private, with a political context, Ode VI is deliberative, political, Ode VII is private, epideictic, Ode VIII is private, deliberative, Ode IX is private, hymnic, Ode $\mathrm{X}$ is private, quasi-hymnic; Ode $\mathrm{XI}$ is private, epideictic, Ode XII is political, epideictic. It also seems important in terms of its composition that the whole cycle is contained within a frame two political odes, each of which is patronised by a different ruler: the first one by the unfortunate Henry III of France, the last one by the triumphant Bathory. In the middle of the cycle, there is Ode VI, which expresses the public feeling of interregnum and the desire to submit oneself to the rule of a good ruler. It is, therefore,

35 See L. P. Wilkinson, Horace and his..., p. 169.

36 J. Budzyński, Horacjanizm w liryce..., pp. 63-90. Budzyński (p. 63) calls this collection an exceptional chapter of Renaissance-humanistic imitation in the work of Jan Kochanowski. More about the concept of the cycle, Z. Głombiowska, Łacińska i polska..., pp. 71-90. Apart from the varietas principle (in terms of metrics, subject matter and functions), Głombiowska also indicates the principle of chronology (p. 85) and "action" (pp. 86-88), both external (political events) and internal (emotions of the subject). 
a precisely composed cycle (also according to the chronological principle, according to Głombiowska, and the associated external and internal "action"), forming an emblematic record of both the historical process and changes of consciousness.

\section{Location in the universe}

It is time to close these observations with a few remarks that fix the position of the Lyricorum libellus collection within the universe of literary genres, and especially within the history of the neo-Latin ode in Poland (against the European background).

Kochanowski's odes show almost no relation with the initial stage of development of this genre in our country, noticeable especially in the area of German cultural influences, while in our area more clearly in the work of Conrad Celtes, Paul of Krosno (Paulus Crosnensis) or Laurentius Corvinus. In this context, the ode could be called a "university" genre ${ }^{37}$ combining prayer, laudation or education with the teaching of linguistic and metrical norms (e.g. in the case of Paul of Krosno ${ }^{38}$ these could be poetic paraphrases of the Lord's Prayer and Hail Mary, a rhymed biography of Horace,

37 See W. Salmen, "European Song: 1300-1530," in: The New Oxford History of Music, vol. 3, ed. by D. A. Hughes, G. Abraham, London 1970 (1960 reprint), p. 370; G. Reese, Music in the Renaissance, New York [1959], p. 705; see also: T. Kostkiewiczowa, Oda w poezji..., pp. 82-84; A. Gorzkowski, Paweł $z$ Krosna. Humanistyczne peregrynacje krakowskiego profesora, Kraków 2000, pp. 246-250.

38 In the poetry of Paul of Krosno, there was also a quite clearly formed hymnic variety of the ode; apart from the hymn to Apollo, numerous hymns to Mary, etc., it is worth mentioning the Sapphic Hymnus in Diem Paschalem continens verni temporis descriptionem; see Paweł z Krosna, Carmina, oprac. M. Cytowska, Warszawa 1962, pp. 181-182. See also: E. Buszewicz, "Obraz Chrystusa zmartwychwstałego w polskiej poezji nowołacińskiej," in: Via pulchritudinis. Wątki biblijne w literaturze $i$ kulturze polskiej [...], red. A. Gorzkowski, Ł. Kamykowski, K. Panuś, Kraków 2010, pp. 268-271. 
etc.). The only link that in some way connects Lyricorum libellus with this current could be the ode In deos falsos, in which one can discern some "doctrinal" character. A custom that consists in combining the ode with the epinicion developed in the history of the genre and was adopted by Kochanowski in Ode XII. In the first half of the $16^{\text {th }}$ century we can see this, for example, in Ioannes Vislicensis' ode on the victory of Orsza. ${ }^{39}$

Kochanowski's ode is part of a universal scheme shaped by the neo-Latin poets active in Italy in the $15^{\text {th }}$ and $16^{\text {th }}$ centuries (Marullo, Pontano), who insisted that the ode (official and ceremonial, and at the same time reflective and philosophical, emotional and suggestive $^{40}$ ) should be combined into cycles organised around a certain idea. ${ }^{41}$ One can also see the influence of French neo-Latin poets, who combined occasional, religious and bucolic motifs in their odes. $^{42}$

Those who laid down the principles of Renaissance poetics usually spoke of "lyrical songs," classifying the ode as one of the varieties of the lyrical genre, whose position within the genological consciousness was only just being consolidated. ${ }^{43}$ In the old system of the division of literary genres, lyric poetry did not have the status of a genre, as one differentiated between genus imitativum (drama, etc.), enarrativum (simple narrations) and mixtum (narration with elements of dialogue-both epic and lyric belonged here [!]) depending on the

39 T. Kostkiewiczowa, Oda w poezji..., p. 83.

40 C. Maddison, Apollo and the Nine..., p. 44. See T. Kostkiewiczowa, Oda w poezji..., p. 74 .

${ }^{41}$ Although Celtes composed his Libri quattuor Odarum, cum Epodo et Saeculari Carmine earlier, this work, as Lawrence V. Ryan brutally notes, can be compared with the output of Horace almost only in terms of quantity. See L.V. Ryan, "Conrad Celtis' Carmen Saeculare. Ode for a New German Age," Acta Conventus Neo-Latini Bononiensis: Proceedings of the Fourth International Congress of Neo-Latin Studies Bologna, 26 August to 1 September 1979, ed. by R.J. Schoeck, Binghamton 1985, p. 594.

42 T. Kostkiewiczowa, Oda w poezji..., p. 74.

43 Ibidem, pp. 77-81. 
ratio of the author's narrative to the dialogue of the characters. However, Antonio Minturno (De poet, 1559) already shows a desire to give lyric poetry the status of a genus. ${ }^{44}$ Reading Kochanowski's cycle indicates a mature awareness of the genre form of the neo-Latin ode, shaped on the borderline between the ode and the hymn, ${ }^{45}$ but also displaying other inter-genre relations, especially under the influence of Horace, as well as an interest in Pindar and Anacreon, characteristic of the second half of the $16^{\text {th }}$ century. The Lyricorum libellus is a studious and carefully arranged poetic cycle.

Translated by Kaja Szymańska

\section{Bibliography}

Brożek M., "Łacińska wersyfikacja Jana Kochanowskiego. Próba charakterystyki," in: Cracovia litterarum. Kultura umysłowa i literacka Krakowa i Małopolski w dobie Renesansu. Księga zbiorowa Międzynarodowej Sesji Naukowej w czterechsetlecie zgonu Jana Kochanowskiego (w Krakowie, 10-13 października 1984 r.), red. T. Ulewicz, Wrocław 1991, pp. 345-348.

Budzyński J., Horacjanizm w liryce polskiej i łacińskiej renesansu i baroku, Wrocław 1985.

Buszewicz E., "Między Eobanem a Buchananem. Poetycka psalmografia Grzegorza z Sambora," Rocznik Przemyski 48 (2012), pp. 21-34.

44 T. Michałowska, Staropolska teoria genologiczna, Wrocław 1974, p. 68.

45 One notices here that in Kochanowski's time Latin psalmic odes were written in Poland. Such texts were created, for example, by Grzegorz of Sambor. So far we know of two paraphrases of psalms included in an edition of the poetic panegyric in honour of St. Anna by Szymon Gorycki (Panegyricum Simonis Goritii Pilsniani De Diva Anna, Matre Virginis Mariae, Carmen, Krakow 1568). These are Ps. 113 (112) Laudate, pueri, Dominum... and Ps. 15 (14) Domine, quis habitabit in tabernaculo tuo... See E. Buszewicz, "Między Eobanem a Buchananem. Poetycka psalmografia Grzegorza z Sambora," Rocznik Przemyski 48 (2012), v. 2, pp. 21-34. 
Buszewicz E., "Obraz Chrystusa zmartwychwstałego w polskiej poezji nowołacińskiej," in: Via pulchritudinis. Wątki biblijne w literaturze i kulturze polskiej. Materiaty konferencji naukowej zorganizowanej przez Komitet Nauk Teologicznych PAN, Wydział Teologiczny UPJPII, Polskie Towarzystwo Teologiczne i Wydział Polonistyki UJ, Kraków, 16-18 listopada 2010, red. A. Gorzkowski, Ł. Kamykowski, K. Panuś, Kraków 2010, pp. 259-275.

Danielewicz J., “Pejzaż semiotyczny w Pieśniach Horacego," Eos 63 (1975), pp. 297302.

Davis G., Polyhymnia. The Rhetoric of Horatian Lyric Discourse, Berkeley 1991.

Eco U., Pejzaż semiotyczny, tłum. A. Weinsberg, Warszawa 1972.

Glomski J., "Historiography as Art. Jan Kochanowski’s Lyricorum libellus (1580)," in: Renaissance Culture in Context. Theory and Practice, ed. by J. R. Brink, W. F. Gentrup, Aldershot 1993, pp. 145-154.

Głombiowska Z., Łacińska i polska muza Jana Kochanowskiego, Warszawa 1988.

Gorycki S., Panegyricum Simonis Goritii Pilsniani De Diva Anna, Matre Virginis Mariae, Carmen, Kraków 1568.

Gorzkowski A., Paweł z Krosna. Humanistyczne peregrynacje krakowskiego profesora, Kraków 2000.

Guiraud P., Semiologia, tłum. S. Cichowicz, Warszawa 1974.

Kochanowski J., Lyricorum libellus, Cracoviae 1580.

Kostkiewiczowa T., Oda w poezji polskiej. Dzieje gatunku, Wrocław 1996.

Maddison C., Apollo and the Nine. A History of the Ode, London 1960.

Michałowska T., Staropolska teoria genologiczna, Wrocław 1974

Parylak P., "O elegiach i odach łacińskich Jana Kochanowskiego z uwzględnieniem poetów klasycznych," in: Sprawozdanie Gimnazjum w Stanisławowie, Lwów 1880 , pp. 3-15.

Paweł z Krosna, Carmina, oprac. M. Cytowska, Warszawa 1962.

Poetyka okresu renesansu, oprac. E. Sarnowska-Temeriusz, Wrocław 1982.

Reese G., Music in the Renaissance, New York [1959].

Revard S., "The Graces in Their Merriment. Pindar and the Light Ode," in: S. Revard, Pindar and the Renaissance Hymn-Ode. 1450-1700, Tempe 2001, pp. 277-317.

Ryan L. V., "Conrad Celtis' Carmen Saeculare. Ode for a New German Age," in: Acta Conventus NeoLatini Bononiensis: Proceedings of the Fourth International Congress of Neo-Latin Studies Bologna, 26 August to 1 September 1979, ed. by R.J. Schoeck, Binghamton 1985, pp. 592-601.

Ryczek W., Rhetorica christiana. Teoria wymowy kościelnej Stanisława Sokołowskiego, Kraków 2011.

Salmen W., European Song: 1300-1530, ed. by D. A. Hughes, G. Abraham, London 1970 (The New Oxford History of Music, vol. 3).

Sarbiewski M.K., "Characteres lyrici seu Horatius et Pindarus - Charaktery liryczne, czyli Horacy i Pindar," in: Praecepta poetica - Wykłady poetyki, tłum. S. Skimina, Wrocław 1958, pp. 44-317. 
Scaliger J. C., Poetices libri septem, Lugdunum (Lyon) 1586.

Szastyńska-Siemion A., "Wstęp," in: Pindar, Wybór poezji, Wrocław 1981 (BN II 199), pp. III-LXXIV.

Wilkinson L. P., Horace and His Lyric Poetry, Cambridge 1951. 